\title{
Hematological Assessment of Benzene Exposure Among Employees in Ras- Elmengar Depository of El-Brega Company, Benghazi
}

\section{Huda Mohamed*}

Faculty of Public Health, University of Benghazi, Benghazi, Libya

\begin{abstract}
Background: Benzene is a toxic chemical, and it is human carcinogenic, it found in the natural and in industry, its exposure can cause hematological health problems as result of metabolites formation in the liver and bone marrow. Aim: this study aimed to evaluate the hematological health effects of benzene exposure among workers in loading and uploading stations at Ras-Elmengar depository of Elbrega Company, Benghazi, Libya. Methods: this study was cross sectional design, and the study sample was 30 participants, 15 exposed workers and 15 non-exposed employees. They were asked to fill a questionnaire about socio-demographic data and symptoms of benzene exposure, also, they were asked to withdrawal a blood samples by a laboratory technician to test Complete blood counts and these data was analyzed by using SPSS. Results: the findings demonstrated a significant difference in CBC of exposed and nonexposed group, which there were reduction in WBC, RBCs and HCT of workers who exposed to benzene. Moreover, there were a positive correlation between the hematological effects of benzene exposure and BMI, years of experience, smoking habits of the workers. Conclusion: the exposure to benzene has negative effects on the workers' blood; and this effect is associated with work duration, furthermore, it is correlated with BMI and smoking habits of the workers. Therefore, safety measure must be applied to protect the empolyees in the company.
\end{abstract}

Keywords: Benzene; Blood test; Hematological effects; Exposure

\section{Introduction}

Benzene is colorless and highly flammable liquid, it is known as benzol. It present in the soil, water and air, and it evaporates quickly into the air [1]. Its sources are natural source such as crude oil and industrial sources such as coal tar and petroleum. In addition, it found in gasoline, cigarette smoking [2]. Benzene consider a public health concern because it is one of the cancer causes [3], which is classified as human carcinogenic (group 1) [4]. It enters the human body though the skin, ingestion and lungs and passes into the bloodstream. Then, it can be stored in the fat tissue and bone marrow, or it can be metabolized into other products in the liver and bone marrow, which are known as metabolites [5]. Some of these metabolites leaves the body within 48 hours of exposure such as conjugated phenols exerted in the urine [5]. While other metabolites could be bio-activated by myeloperoxidases and other heme-protein peroxidases to reactive semiquinones and quinones, these products cause reactive oxygen species (ROS) formation [6] ROS involves superoxide radical anion, hydroperoxyl radical, hydrogen peroxide $\left(\mathrm{H}_{2} \mathrm{O}_{2}\right)$, and the highly reactive hydroxyl radical [6]. These could lead to reduce the levels of all cellular elements in the bone marrow and the peripheral blood, and it can be manifested as pancytopenia and a plastic anemia [7]. Also, it can lead to bleeding and effect on the immune system function, and that can rise the chance for getting infection [8]. Furthermore, chronic exposure to benzene lead to decrease in the erythrocytes and leukocytes production, and that resulting in anemia [9], also, it causes myeloid leukaemia, thrombocytopenia [5]. Moreover, exposure to benzene can cause neurotoxicity [10], immunitoxicity [11] and it can cause damage to the liver and kidney [12]. The health surveillance of benzene in the human body include periodic tests for complete blood counts, test of $\mathrm{t}, \mathrm{t}$-muconic aid in the urine [9]. This study will focus on the haematological effects of benzene exposure.

Aim of study: to evaluate the haematological effects of benzene exposure on the workers in loading and uploading stations at RasElmengar depository of Elbrega Company, and evaluate its relation with some vaiables (BMI, smoking and years of experience).

\section{Methods and Materials}

A cross sectional study was conducted in Rar-Elmengar depository of Al-Brega Company, Benghazi, Libya. The sample involved 30 workers, they were classified into two groups; exposed group included all workers in loading and uploading stations, and non-exposed group included the workers in the offices, which were 15 workers in each group. The sample was homogenous, which all the workers were male. The data was collected by using multiple choices questionnaire and taking blood sample from the participants after getting approval permission from this company. The questionnaire included six socio-demographic questions and eight questions about acute health effects on benzene exposure. The blood sample was taken by specialized technician to test Complete Blood Count CBC and assess the differences between two groups; this data was collected from 4 to 22 of June 2017, and then analyzed by statistical package for social sciences software version 22 .

\section{Results}

Table 1 present the demographic information of the participants, all the sample was men, and the largest proportion of exposed and nonexposed group were their age between 41 and 50 years, and the largest proportion of control group was overweight with body mass index 30 or more, While the majority of cases have a normal weight with BMI 25-29.99.

Table 2 shows the blood parameter values of benzene-exposed workers, these values are classified into three categories; below normal,

${ }^{*}$ Corresponding author: Huda Mohamed, Faculty of Public Health, University of Benghazi, Benghazi, Libya, Tel: +218916766646; E-mail: huda.mohamed@uob.edu.ly

Received July 05, 2018; Accepted July 22, 2018; Published July 28, 2018

Citation: Mohamed H (2018) Hematological Assessment of Benzene Exposure Among Employees in Ras-Elmengar Depository of El-Brega Company, Benghazi. J Environ Anal Toxicol 8: 581. doi: 10.4172/2161-0525.1000581

Copyright: ๑ 2018 Mohamed H. This is an open-access article distributed under the terms of the Creative Commons Attribution License, which permits unrestricted use, distribution, and reproduction in any medium, provided the original author and source are credited. 
Citation: Mohamed H (2018) Hematological Assessment of Benzene Exposure Among Employees in Ras-Elmengar Depository of El-Brega Company, Benghazi. J Environ Anal Toxicol 8: 581. doi: 10.4172/2161-0525.1000581

Page 2 of 4

normal and above normal. This study found that 5 out of 15 workers have lower Red Blood Cell (RBC) and 6 workers have low value of White Blood Cell, in addition, 10 exposed workers have lower haematocrit value, on the other hand, the values of haemoglobin, platelets and corpuscular volume (MCV) were normal among exposed group. According to Table 3, the current study suggested that there was no differences in HGB, HCT, PLT and MCV between the exposed and the unexposed groups, however, there was a significant differences between them in RBC and WBC counts because P value were less than 0.05 .

Furthermore, the symptoms of benzene exposure appears among exposed group more than case group, and the most common symptoms were Exhaustion and Dizziness (Figure 1). Additionally, ANOVA test was used to compare the association between the hematological effects of benzene on exposed and non-exposed group and demographic variables, which are age, BMI, level of education, smoking habits, and

\begin{tabular}{|c|c|c|c|}
\hline \multicolumn{2}{|c|}{ Variables } & \multirow{2}{*}{$\begin{array}{c}\begin{array}{c}\text { Exposed } \\
\text { group }\end{array} \\
15\end{array}$} & \multirow{2}{*}{$\begin{array}{c}\begin{array}{c}\text { Non-exposed } \\
\text { group }\end{array} \\
15\end{array}$} \\
\hline & Male & & \\
\hline Genuer & Female & 0 & 0 \\
\hline \multirow{5}{*}{ Age } & $20-30$ & 2 & 2 \\
\hline & $31-40$ & 3 & 4 \\
\hline & $41-50$ & 9 & 6 \\
\hline & $51-60$ & 1 & 3 \\
\hline & More than 61 & 0 & 0 \\
\hline \multirow{3}{*}{ Body Mass Index (BMI) } & $18.5-24.99$ & 4 & 4 \\
\hline & 25- 29.9 & 6 & 4 \\
\hline & 30 or more & 5 & 7 \\
\hline \multirow{6}{*}{ Experience years } & $0-5$ & 3 & 3 \\
\hline & $6-10$ & 3 & 0 \\
\hline & $11-15$ & 2 & 1 \\
\hline & $16-20$ & 2 & 2 \\
\hline & $21-25$ & 3 & 5 \\
\hline & More than 26 & 2 & 4 \\
\hline \multirow{3}{*}{ Smoking habits } & Never & 4 & 4 \\
\hline & Current smoker & 9 & 7 \\
\hline & Previous smoker & 2 & 4 \\
\hline
\end{tabular}

Table 1: Participants' demographics.

\begin{tabular}{|c|c|c|}
\hline Blood parameters & Category & Frequency \\
\hline \multirow{3}{*}{ RBC } & Below normal & 5 \\
\cline { 2 - 3 } & Normal & 10 \\
\cline { 2 - 3 } & Above normal & 0 \\
\hline \multirow{3}{*}{ WBC } & Below normal & 6 \\
\cline { 2 - 3 } & Normal & 7 \\
\cline { 2 - 3 } & Above normal & 2 \\
\hline \multirow{3}{*}{ HCT } & Below the normal & 10 \\
\hline \multirow{3}{*}{ HB } & Normal & 5 \\
\hline \multirow{3}{*}{ PLT } & Above normal & 0 \\
\hline & Below normal & 0 \\
\hline \multirow{3}{*}{ MCV } & Normal & 15 \\
\hline & Above normal & 0 \\
\hline & Below normal & 0 \\
\hline & Normal & 15 \\
\hline & Above normal & 0 \\
\hline & Below normal & 0 \\
\hline & Normal & 15 \\
\hline & Above normal & 0 \\
\hline
\end{tabular}

Table 2: Complete blood counts of benzene exposed workers.

\begin{tabular}{|c|c|c|}
\hline Parameter & Mean & P value \\
\hline RBC & 4.8 & 0.01 \\
\hline HGB & 14.5 & 0.07 \\
\hline WBC & 7.09 & 0.02 \\
\hline HCT & 43.5 & 0.06 \\
\hline PLT & 276.4 & 0.06 \\
\hline MCV & 89.2 & 0.06 \\
\hline
\end{tabular}

Table 3: Haematological parameters of exposed and non-exposed group using chi-square test.

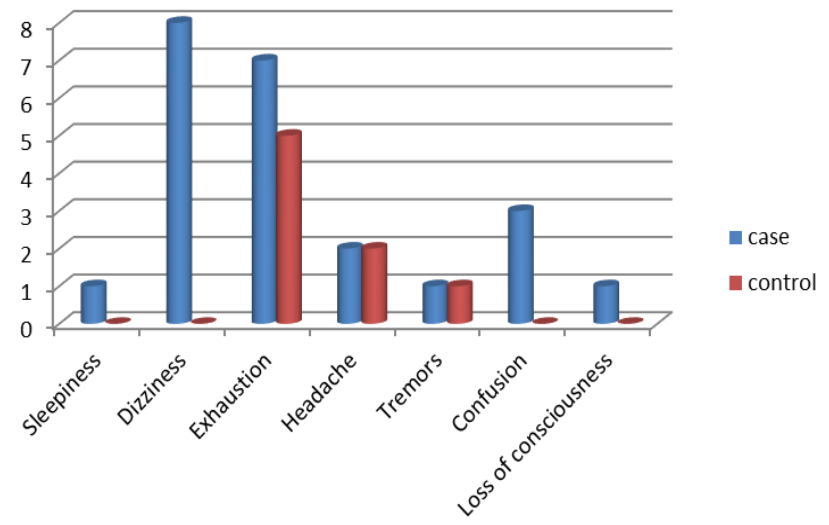

Figure 1: Frequency of benzene exposure symptoms among cases and control groups.

years of experience. Furthermore, Table 4 demonstrated that there is a significant association between hematological effects of benzene (on cases versus control group) and workers' Body Mass Index, since the $\mathrm{P}$ value for all blood parameter were less than 0.05 . According to Table 5, there was a positive relationship between work duration and effects of benzene on the exposed workers' blood because $\mathrm{P}$ value $<0.05$. Moreover, Table 6 indicated that smoking habits was significantly correlated to the hematological effects of benzene, since P were less than 0.05 .

\section{Discussion}

The present study showed decline in the counts of WBC, RBC and HCT, this result come in agreement with studies have been conducted by Rothman et al. [13] and Ibrahim et al. [14]. They found a significantly decrease in total RBC and WBCs, in addition to decrease in platelets levels. Besides, $\mathrm{Qu}$ et al. indicated that exposure to benzene lead to decrease the levels of RBC, WBCs, and neutrophils [15]. Moreover, Agabeldour et al. found some effects from benzene exposure on blood counts of exposed workers, which they found drop in Reticulocytes, HCT and red cell indices in all workers [16]. Furthermore, Kirkeleit et al. found a clear relation between chronic benzene exposures with hematological effects, they indicated reduce in neutrophil, lymphocyte and platelet counts of peripheral blood [17]. Conversely, Liao studied the effects of benzene on the workers blood over 5 years from 2001 to 2005 , they suggested that there is no relation between benzene exposure and blood parameters, which he found that no differences in $\mathrm{CBC}$ between exposed and non-exposed. However, he found that eosinophils level was higher among exposed group [18].

In addition, the current study demonstrated that BMI of the workers associated significantly with effects of benzene on peripheral blood (Table 3). This finding is in agreement with Kamal and Rashid study in 2014 [19], they found a significant correlation between benzene 
Citation: Mohamed H (2018) Hematological Assessment of Benzene Exposure Among Employees in Ras-Elmengar Depository of El-Brega Company, Benghazi. J Environ Anal Toxicol 8: 581. doi: 10.4172/2161-0525.1000581

Page 3 of 4

\begin{tabular}{|c|c|c|}
\hline & ANOVA & P-value \\
\hline RBC & 255.751 & 0.000 \\
\hline HGB & 211.667 & 0.000 \\
\hline WBC & 8.861 & 0.006 \\
\hline HCT & 248.921 & 0.000 \\
\hline PLT & 12.251 & 0.002 \\
\hline MCV & 1877.294 & 0.000 \\
\hline
\end{tabular}

Table 4: Association between hematological effects of benzene (cases and control group) and workers' BMI using ANOVA test.

\begin{tabular}{|c|c|c|}
\hline & ANOVA & P-value \\
\hline RBC & 484.277 & 0.000 \\
\hline HGB & 3994.696 & 0.000 \\
\hline WBC & 11.194 & 0.002 \\
\hline HCT & 459.255 & 0.000 \\
\hline PLT & 62.546 & 0.000 \\
\hline MCV & 2646.956 & 0.000 \\
\hline
\end{tabular}

Table 5: Association between hematological effects of benzene (cases and control group) and workers' years of experience using ANOVA test.

\begin{tabular}{|c|c|c|}
\hline & ANOVA & P-value \\
\hline RBC & 507.879 & 0.000 \\
\hline HGB & 400.033 & 0.000 \\
\hline WBC & 13.806 & 0.001 \\
\hline HCT & 455.115 & 0.000 \\
\hline PLT & 44.314 & 0.000 \\
\hline MCV & 2764.725 & 0.000 \\
\hline
\end{tabular}

Table 6: Association between hematological effects of benzene (cases and control group) and workers' smoking habits using ANOVA test.

exposure effects and workers' BMI. On the other hand, Rothman et al., did not find any significant changes between the blood parameters of exposed workers and their BMI [20].

Additionally, the findings of present study showed a significant association between experience years and effects of benzene on peripheral blood of exposed workers. In more details, it demonstrated that increases of the workers' experience years' means that increasing the effects of benzene exposure on blood (Table 4). Similarly, study reported in Pakistan [19], they found indicated a positive association between the blood and years of experience. Besides, Kozlova et al. indicated that extent of the benzene hematological effects were correlated with exposure duration, which the severity changes in blood counts were observed among workers how exposed to high levels and exposed for long period of time [21]. Contrary, Ibrahim et al. demonstrated that benzene exposure duration did not statistically correlated with blood and urine parameter of the exposed workers [14].

Furthermore, the results of current study demonstrated a positive relationship between smoking habits and hematological effects of benzene exposure, which it found clear differences between workers who were smokers and who were not smoker (Table 5). The reasons for that could be a benzene content in Cigarette smoking, which increase the level of exposed benzene [22]. Moreover, Kamal and Rashid indicated that smoking habits has appositive correlation with hematologic effects of benzene [19]. Besides, Hajimiragha et al. and, Pekari et al. indicated that cigarette smoking is a potential factor for low benzene monitoring $[23,24]$. Alternatively, Rothman et al. carried out study on benzene poisoning and risk factor, they found the smoking status was not significantly associated with benzene poisoning [20].

\section{Conclusion}

The present study indicated that there werhe a drop in RBC, WBC and HCT counts of workers who exposed to benzene. In addition, it indicated that years of experience, BMI and smoking habits of the works are significantly correlated with effects of benzene on the blood. Therefore, this study recommended periodical health examination of the workers with routinely complete blood counts test to detect the early haematological effects of benzene exposure.

\section{References}

1. HSE (2012) Benzene and you. Health and Safety Executive. UK. Available online from: http://www.hse.gov.uk/pubns/indg329.pdf

2. Agency for Toxic Substances and Disease Registry (2007) Toxicological Profile for Benzene. US Department of Health and Human Services. Public Health Service Agency for Toxic Substances and Disease Registry.

3. IARC (1987) Summaries \& evaluations: Benzene (Group 1). International Agency for Research on Cancer. IARC Monographs on the Carcinogenicity of Chemicals to Humans, Supplement 7. Lyon, p: 120. Available from: http:// www.inchem.org/documents/iarc/suppl7/benzene.html

4. Baan R, Grosse Y, Straif K, Secretan B, El Ghissassi F, et al. (2009) A review of human carcinogens - Part $F$ : chemical agents and related occupations. The Lancet Oncology 10: 1143-1144.

5. Aw TC, Gardiner K, Harrington JM (2013) Occupational health: Pocket consultant. John Wiley \& Sons.

6. Elsayed AS (2015) Hematotoxicity and oxidative stress caused by benzene Pyrex Journal of Biomedical Research 1: 74-80.

7. Health Council of the Netherlands (2014) Benzene - Health-based recommended occupational exposure limit. The Hague: Health Council of the Netherlands. Publication No. 2014/03.

8. CDC (2013) NIOSH Pocket Guide to Chemical Hazards, Benzene. Available online from: https://www.cdc.gov/niosh/npg/npgd0049.html

9. WHO (1993) Benzene. International Programme on Chemical Safety. Environmental Health Criteria, 150 Geneva. Available online at: http://www. inchem.org/documents/ehc/ehc/ehc150.htm

10. Pumo RL, Bellia M, Nicosia A, Micale V, Drago F (2006) Long-lasting neurotoxicity of prenatal benzene acute exposure in rats. Toxicology 223: 227-234.

11. Bogadi-Šare A, Zavalić M, Trošić I, Turk R, Kontošić I, et al. (2000) Study of some immunological parameters in workers occupationally exposed to benzene. International Archives of Occupational and Environmental Health 73: $397-400$.

12. El-Shakour AA, El-Ebiarie AS, Ibrahim YH, Moneim AE, El-Mekawy AM (2015) Effect of benzene on oxidative stress and the functions of liver and kidney in rats. J Environ Occup Sci 4: 34-39.

13. Rothman N, Li GL, Dosemeci M, Bechtold WE, Marti GE, et al. (1996) Hematotoxocity among Chinese workers heavily exposed to benzene. American Journal of Industrial Medicine 29: 236-246.

14. Ibrahim KS, Amer NM, El-Dossuky EA, Emara AM, El-Fattah AE, et al. (2014) Hematological effect of benzene exposure with emphasis of muconic acid as a biomarker. Toxicology and Industrial Health 30: 467-474.

15. Qu Q, Shore R, Li G, Jin X, Chen LC, et al. (2003) Validation and evaluation of biomarkers in workers exposed to benzene in China. Research Report (Health Effects Institute) 115: 1-72.

16. Agabeldour AA, Khalafallah TO, AbdAllah AM (2015) Hematological changes among Sudanese petroleum workers with a broad range of benzene exposure. Sch J App Med Sci 3: 3054-3056.

17. Kirkeleit J, Riise T, Gjertsen BT, Moen BE, Bråtveit M, et al. (2008) Effects of benzene on human hematopoiesis. The Open Hematology Journal 2: 87-102.

18. Liao YH (2015) Hematological effects of benzene in the petroleum industry. International Journal of Health 3: 1-2.

19. Kamal A, Rashid A (2014) Benzene exposure among auto-repair workers from workplace ambience: A pioneer study from Pakistan. International Journal of Occupational Medicine and Environmental Health 27: 830-839. 
Citation: Mohamed H (2018) Hematological Assessment of Benzene Exposure Among Employees in Ras-Elmengar Depository of El-Brega Company, Benghazi. J Environ Anal Toxicol 8: 581. doi: 10.4172/2161-0525.1000581

Page 4 of 4

20. Rothman N, Smith MT, Hayes RB, Traver RD, Hoener BA, et al. (1997) Benzene poisoning, a risk factor for hematological malignancy, is associated with the NQO1 $609 \mathrm{C} \rightarrow \mathrm{T}$ mutation and rapid fractional excretion of chlorzoxazone. Cancer Research 57: 2839-2842.

21. Kozlova TA, Volkova AP (1960) The blood picture and phagocyte activity of leukocytes in workers having contact with benzene. Gigiena i Sanitariia 25: 29-34.

22. Goldstein BD, Witz G (2009) Benzene. Environmental Toxicants: Human Exposures and their Health Effects. 3rd edn. John Wiley \& Sons, pp: 459-498.
23. Hajimiragha $\mathrm{H}$, Ewers U, Brockhaus A, Boettger A (1989) Levels of benzene and other volatile aromatic compounds in the blood of non-smokers and smokers. International Archives of Occupational and Environmental Health 61: 513-518.

24. Pekari K, Vainiotalo S, Heikkilä P, Palotie A, Luotamo M, et al. (1992) Biological monitoring of occupational exposure to low levels of benzene. Scandinavian Journal of Work, Environment \& Health 1: 317-322. 